\title{
PRODUKTIVITAS ALAT TANGKAP PANCING ULUR (HAND LINE) PADA RUMPON PORTABLE DI PERAIRAN KABUPATEN ACEH UTARA
}

\section{PRODUCTIVITY OF HAND LINE ON PORTABLE FADS IN THE WATER OF NORTH ACEH DISTRICT}

\author{
Imam Shadiqin ${ }^{1}$, Roza Yusfiandayani' ${ }^{2}$ Mohammad Imron ${ }^{2}$ \\ ${ }^{1}$ Program Studi Teknologi Perikanan Laut, \\ ${ }^{2}$ Departemen Pemanfaatan Sumberdaya Perairan, \\ Fakultas Perikanan dan Ilmu Kelautan, Intitut Pertanian Bogor \\ Korespondensi: imam_shadiqin@yahoo.com
}

\begin{abstract}
The rumpon portable is a fishing auxiliary device that functions to collect fish with $11,000-15,000 \mathrm{~Hz}$ frequencey by using sound on the atractors of portable FADs that be able to collect small pelagic fish around portable FADs. The small pelagic fish have habit to configurate a schooling group in their lives for migrating, feeding, and spawning. The hand line is one of fishing gear used by small-scale fisherman to catch small pelagic fish. Therefore, it is important to know about productivity of handline on the portable FADs. This study used production data of handline with 15 fishing trips in August-September 2018 located in the waters of North Aceh. The result showed that 8 types, that is selar tetengkek (Megalaspis cordyla), pompano (Caranx ignobilis), grauper (Epinephelus fuscoguttatus), selar (Selaroides leptolepis), squid (Loligo indica), turmeric (Upeneus moluccensis), barred (Scomberomorini), and mackerel (Rastrelliger) with a total weight of $24,25 \mathrm{~kg}$ was caught around portable FADs using handline. The average productivity of handline on the portable FADs was $1,61 \mathrm{~kg} /$ trip. The catch composition showed that the dominant catch was squid.
\end{abstract}

Keyword: catch productivity, hand line, north Aceh, rumpon portable

\begin{abstract}
ABSTRAK
Rumpon portable merupakan suatu jenis alat bantu yang berfungsi untuk mengumpulkan ikan dengan frekuensi sebesar $11.000-15.000 \mathrm{~Hz}$, dengan metode penggunaan suara pada atraktor yang ada pada rumpon portable sehingga ikan-ikan pelagis kecil berkumpul di sekitar rumpon portable. Ikan pelagis kecil memiliki kebiasaan hidup membentuk gerombolan dalam melangsungkan hidupnya, baik itu bermigrasi, mencari makan, bahkan memijah. Pancing ulur merupakan salah satu alat tangkap yang digunakan nelayan skala kecil untuk aktifitas penangkapan ikan pelagis kecil, oleh karena itu diperlukan penelitian tentang produktivitas pancing ulur pada rumpon portable. Penelitian ini menggunakan data produksi dari alat tangkap pancing ulur, dengan jumlah pengambilan data selama 15 trip penangkapan pada bulan Agustus-September 2018 bertempat di perairan Aceh Utara. Hasil penelitian menunjukkan jenis dan jumlah ikan yang tertangkap disekitar rumpon portable dengan menggunakan alat tangkap pancing ulur di antaranya ada 8 jenis yaitu ikan selar tetengkek (Megalaspis cordyla), kue (Caranx ignobilis), kerapu (Epinephelus fuscoguttatus), selar (Selaroides leptolepis), cumicumi (Loligo indica), kuniran (Upeneus moluccensis), tenggiri (Scomberomorini) dan kembung (Rastrelliger) dengan total berat $24,25 \mathrm{~kg}$. Rata-rata produktivitas penangkapan ikan dengan alat tangkap pancing ulur pada rumpon portable sebesar $1,61 \mathrm{~kg} /$ trip. Komposisi jenis ikan hasil tangkapan menunjukkan cumi-cumi dominan tertangkap dengan alat tangkap pancing ulur yang dioperasikan di sekitar rumpon portable.
\end{abstract}

Kata kunci: Aceh Utara, pancing ulur, produktivitas penangkapan, rumpon portable 


\section{PENDAHULUAN}

\section{Latar belakang}

Perairan Aceh Utara merupakan salah satu perairan yang sangat strategis yang ada di perairan Aceh, dimana perairan Aceh Utara berbatasan langsung dengan Selat Malaka dan perairan negara Malaysia dengan kondisi perairan yang memiliki ketinggian gelombang bekisar 0,5 sampai 0,8 m (BMKG 2018). Salah satu aktivitas yang ada di perairan Aceh Utara adalah perikanan tangkap, aktivitas perikanan tangkap di perairan Aceh Utara sudah termasuk dalam katagori skala besar dimana nelayan sudah menggunakan rumpon dalam skala besar untuk melakukan aktivitas perikanan tangkap (Adwani 2011). Uktolseja et al. (1989) menyebutkan ada beberapa jenis ukuran kapal yang beroperasi menangkap ikan di sekitar pantai yaitu 3,6 GT, 7,5 GT dan 14 GT. Ukuran kapal yang digunakan untuk melakukan aktivitas penangkapan ikan dengan menggunakan alat tangkap pancing ulur yaitu berukuran 3 dan 5 GT yang termasuk nelayan skala kecil (Jaliadi 2017).

Pancing ulur (hand line) merupakan salah satu jenis alat penangkapan ikan yang sering digunakan oleh nelayan yang berbasis Aceh Utara untuk menangkap ikan di laut. Struktur utama dari alat tangkap pancing ulur terdiri dari mata pancing, swivel, tali pancing, pemberat serta umpan. Operasional penangkapan pancing juga menggunakan alat bantu seperti umpan dan rumpon. Hasil penelitian Syari et al. (2014) menunjukkan daerah penangkapan ikan bisa di rekayasa dengan penggunaan rumpon di perairan.

Rumpon portable adalah suatu alat bantu dalam aktivitas perikanan tangkap yang berfungsi untuk mengumpulkan ikan dengan menggunakan konsep respon pendengaran pada ikan, frekuensi suara yang keluar dari atraktor rumpon tersebut sebesar 11.000-15.000 Hz, frekuensi suara yang digunakan bervariasi dari infrasonik sampai ultra sonik. Rumpon portable juga merupakan alat bantu yang sangat ramah lingkungan serta mudah dipindahkan ketika operasi penangkapan selesai dilakukan, pada saat proses aktifitas penangkapan berlangsung, rumpon akan diletakkan di sekitar daerah penangkapan.

Muhamad et al. (2017) menyatakan produktivitas alat tangkap yang dioperasikan di sekitar rumpon cukup bervariasi antara 0,1-4,5 ton/trip, dengan nilai rata-rata 0,9 ton/trip. Hal tersebut mendorong nelayan untuk memasang rumpon-rumpon baru sehingga jumlah rumpon yang dipasang oleh nelayan pun semakin banyak, khususnya nelayan skala besar yang berbasis di perairan Aceh Utara. Nelayan di Aceh Utara terbagi menjadi dua, yaitu nelayan skala besar dan nelayan skala kecil. Nelayan skala kecil yang dominan berada di Aceh Utara umumnya menggunakan alat tangkap pancing sebagai alat tangkap untuk melakukan aktivitas penangkapan ikan. Namun, pada beberapa tahun terakhir hasil tangkapan dengan menggunakan pancing ulur mengalami penurunan sehingga dikhawatirkan akan berdampak pada keberlanjutan usaha penangkapan ikan khususnya nelayan skala kecil. Hal tersebut memicu timbulnya inovasi teknologi baru yang dapat meningkatkan produktivitas penangkapan, salah satunya adalah rumpon portable. Rumpon portable adalah suatu inovasi yang berkembang dari rumpon tradisional yang menggunakan konsep respon pendengaran pada ikan yang dikaitkan dengan suatu frekuensi suara yang keluar dari atraktor rumpon tersebut (Yusfiandayani et al. 2013). Menurut Shadiqin et al. (2016) konsentrasi suhu dan klorofil-a yang ada di permukaan laut mempengaruhi hasil tangkapan, dengan begitu kesuburan perairan juga merupakan salah satu faktor yang mempengaruhi hasil tangkapan. Suhu rata-rata di perairan Kota Lhokseumawe yaitu antara $27^{\circ} \mathrm{C}$ sampai $29^{\circ} \mathrm{C}$, sedangkan tingkat konsentrasi ratarata klorofil-a di perairan Kota Lhokseumawe yaitu dari $0,180 \mathrm{mg} / \mathrm{m}^{3}$ sampai 0,635 mg/ $\mathrm{m}^{3}$ (Shadiqin et al. 2016). Rasidi et al. (2002) menyebutkan banyaknya komunitas plankton di sekitar daerah pengoperasian rumpon mengakibatkan ikan pelagis kecil banyak yang datang. Priatna et al. (2010) menyatakan ikan pelagis cenderung berada di depan rumpon terhadap datangnya arus.

Penggunaan alat bantu rumpon sangat membantu meningkatkan efektifitas dan efisiensi dalam proses penangkapan. Perkembangan penggunaan rumpon yang berlangsung sangat pesat menimbulkan keanekaragaman dalam pembuatan bentuk rumpon salah satunya adalah rumpon portable, dengan begitu produktivitas pancing ulur pada rumpon portable di perairan Aceh Utara perlu diteliti. Penelitian ini dilakukan untuk melihat produktivitas hasil tangkapan pancing ulur terhadap rumpon portable di Perairan Aceh Utara dan melihat komposisi hasil tangkapan di setiap stasiun penangkapan. 


\section{METODE PENELITIAN}

\section{Waktu dan tempat}

Aktivitas pengambilan data menggunakan metode experimental fishing yang dilakukan di perairan Aceh Utara selama 15 hari mulai tanggal 25 Agustus - 10 September 2018 (Gambar 1). Waktu pengambilan data dilakukan pada pagi sampai siang hari dengan mencatat langsung.

\section{Alat dan bahan}

Alat dan bahan yang digunakan dalam penelitian ini digunakan untuk skala lapangan, peralatan yang digunakan untuk uji coba lapangan adalah kapal ukuran 2 GT, rumpon portable, tali tambang, GPS, hand camera, underwater camera dan alat tangkap yaitu pancing ulur. Skala pengujian EFA dilakukan di perairan Aceh Utara dengan menggunakan frekuensi sebesar $11.000-15.000 \mathrm{~Hz}$, pada stasiun penangkapan yang berbeda di setiap harinya. Sebagaimana terlihat pada Gambar
1, pengambilan data dilakukan pada musim muson timur, yaitu pada bulan AgustusSeptember 2018. Data kordinat dan hasil tangkapan diperoleh dengan mengikuti secara langsung operasi penangkapan ikan. Pencatan data hasil tangkapan dilakukan berdasarkan jenis ikan yang tertangkap, sedangkan data koordinat penangkapan diperoleh dengan menggunakan Global Positioning System (GPS) pada saat melakukan aktivitas penangkapan di setiap stasiun penangkapan.

Analisis data yang digunakan untuk mencapai tujuan penelitian sebagai berikut: Produktivitas penangkapan ditentukan berdasarkan perbandingan antara produksi dengan jumlah trip penangkapan pada alat tangkap pancing ulur. berikut:

Persamaan yang digunakan sebagai

$$
\operatorname{Prd}=\frac{c}{f}
$$

Dimana, $\operatorname{Prd}=$ produktivitas $(\mathrm{kg} / \mathrm{trip}) ; c=$ jumlah hasil tangkapan $(\mathrm{kg}) ; f=$ jumlah trip penangkapan ikan.

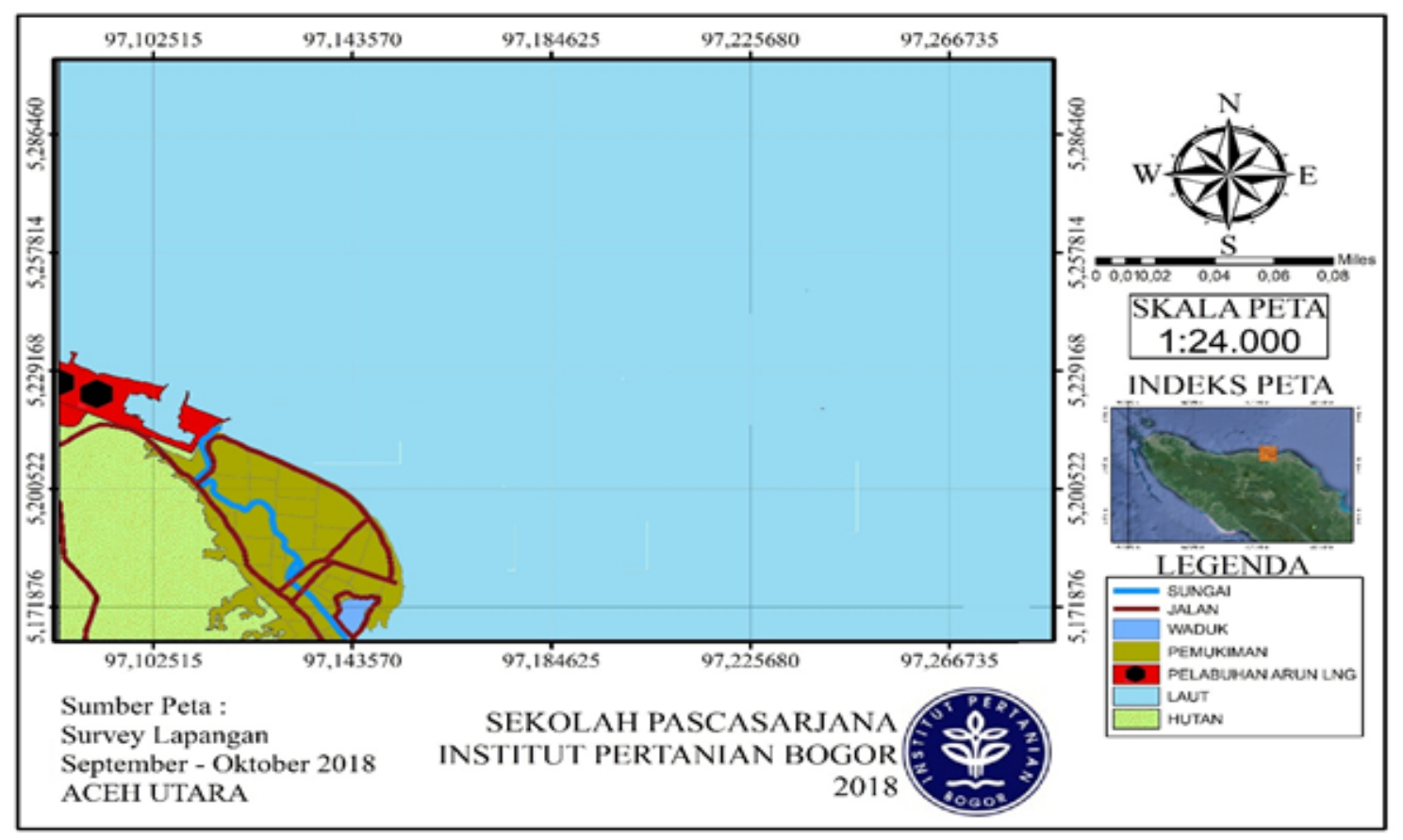

Gambar 1. Lokasi pengambilan data di perairan Aceh Utara

\section{HASIL DAN PEMBAHASAN}

\section{Komposisi jenis hasil tangkapan}

Produksi jenis ikan pelagis kecil di perairan Aceh Utara berdasarkan alat tangkap yang digunakan yaitu pancing ulur menunjukkan adanya perbedaan jenis ikan dan jumlah produksi dari setiap stasiun penangkapan. Hasil tangkapan dari alat tangkap pancing ulur menunjukkan adanya 8 jenis ikan yang tertangkap di setiap stasiun penangkapan yang berbeda (Tabel 1 dan Gambar 2). 
Tabel 1. Daerah penangkapan ikan pelagis kecil

\begin{tabular}{|c|c|c|c|c|}
\hline No & Hari / Tg1 / Bulan & Lintang & Bujur & Jenis ikan yang tertangkap \\
\hline 1 & Sabtu 25 Agustus & $5.205524^{\circ} \mathrm{N}$ & $97.182226^{\circ} \mathrm{E}$ & selar tetengek, selar, cumi \\
\hline 2 & Senin 27 Agustus & $5.263696^{\circ} \mathrm{N}$ & $97.174382^{\circ} \mathrm{E}$ & $\begin{array}{l}\text { kembung, kuniran, kerapu, } \\
\text { cumi-cumi }\end{array}$ \\
\hline 3 & Rabu 29 Agustus & $5.218783^{\circ} \mathrm{N}$ & $97.148956^{\circ} \mathrm{E}$ & selar, cumi-cumi \\
\hline 4 & Sabtu 1 September & $5.241676^{\circ} \mathrm{N}$ & $97.202732^{\circ} \mathrm{E}$ & $\begin{array}{l}\text { tenggiri, selar, kuniran, } \\
\text { cumi-cumi }\end{array}$ \\
\hline 5 & Selasa 4 September & $5.240532^{\circ} \mathrm{N}$ & $97.223461^{\circ} \mathrm{E}$ & kuniran, selar, cumi-cumi \\
\hline 6 & Kamis 6 September & $5.229784^{\circ} \mathrm{N}$ & $97.168599^{\circ} \mathrm{E}$ & selar \\
\hline 7 & Minggu 9 September & $5.223370^{\circ} \mathrm{N}$ & $97.219748^{\circ} \mathrm{E}$ & selar, cumi-cumi \\
\hline 8 & Selasa 11 September & $5.288370^{\circ} \mathrm{N}$ & $97.212383^{\circ} \mathrm{E}$ & selar, cumi-cumi \\
\hline 9 & Kamis 13 September & $5.221770^{\circ} \mathrm{N}$ & $97.140089^{\circ} \mathrm{E}$ & kue, kuniran, cumi-cumi \\
\hline 10 & Minggu 16 September & $5.228888^{\circ} \mathrm{N}$ & $97.130812^{\circ} \mathrm{E}$ & selar \\
\hline 11 & Selasa 18 September & $5.228973^{\circ} \mathrm{N}$ & $97.170631^{\circ} \mathrm{E}$ & kembung \\
\hline 12 & Kamis 20 September & $5.290797^{\circ} \mathrm{N}$ & $97.181440^{\circ} \mathrm{E}$ & selar, cumi-cumi \\
\hline 13 & Minggu 23 September & $5.229765^{\circ} \mathrm{N}$ & $97.146498^{\circ} \mathrm{E}$ & selar, kerapu \\
\hline 14 & Selasa 25 September & $5.213201^{\circ} \mathrm{N}$ & $97.144671^{\circ} \mathrm{E}$ & selar \\
\hline 15 & Kamis 27 September & $5.202567^{\circ} \mathrm{N}$ & $97.167372^{\circ} \mathrm{E}$ & cumi-cumi \\
\hline
\end{tabular}

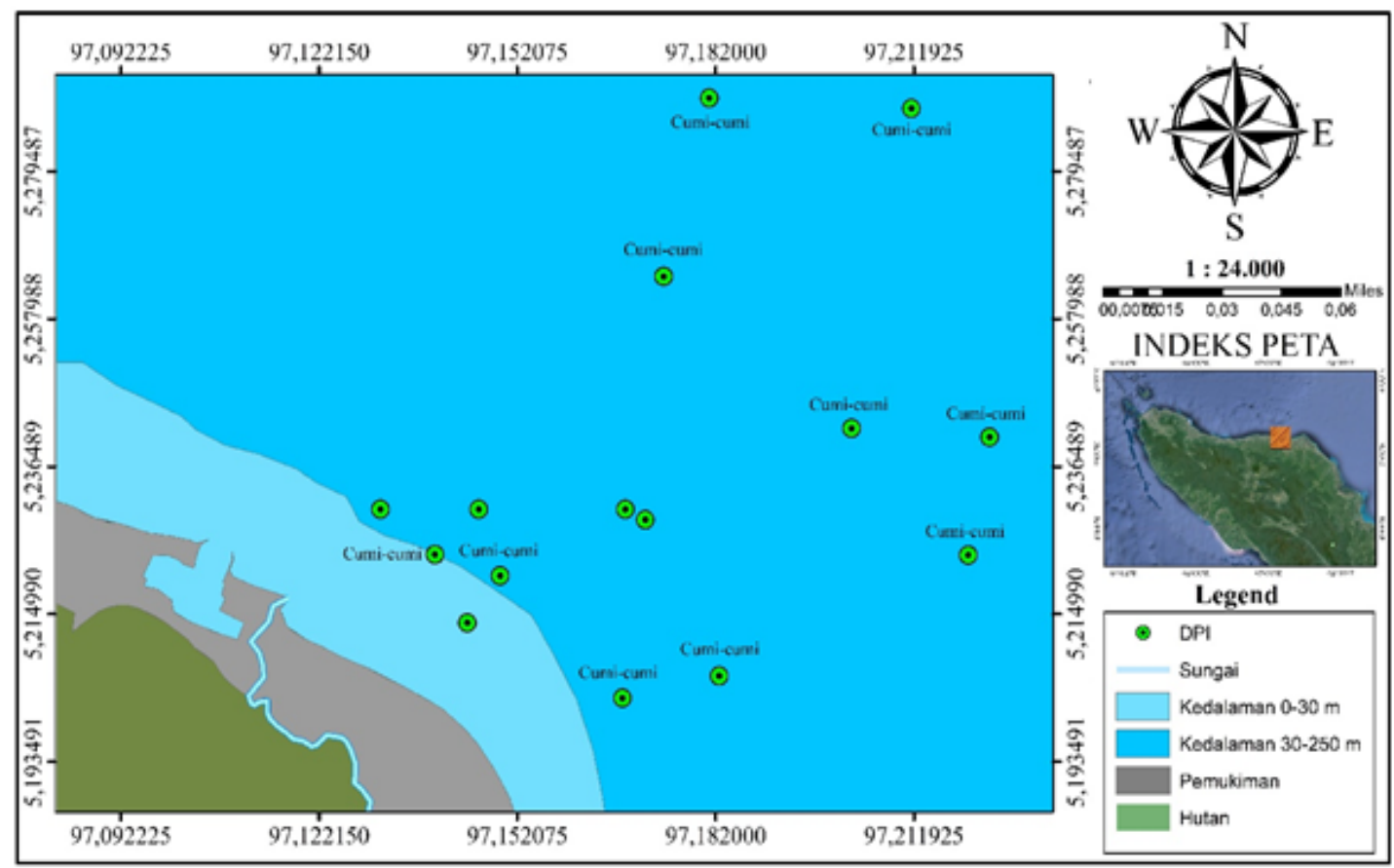

Gambar 2. Lokasi daerah penangkapan ikan pelagis kecil di perairan Aceh Utara

Gambar 2 menunjukkan jumlah hasil tangkapan pada alat tangkap pancing ulur selama 15 hari di setiap stasiun yang berbeda. Jenis ikan cumi-cumi dominan tertangkap disetiap waktu penarikan alat tangkap pancing ulur. Komposisi jenis ikan hasil tangkapan merupakan indikasi keberadaan ikan di daerah tersebut, dimana operasi penangkapan dengan pancing ulur dilakukan. Pola operasi penangkapan dengan menggunakan alat tangkap pancing ulur menunjukkan perpindahan lokasi penangkapan walaupun dengan jarak yang relatif tidak jauh. Dominan hasil tangkapan yang diperoleh oleh alat tangkap pancing ulur yaitu jenis ikan cumicumi, mengindikasikan bahwa ketertarikan cumi-cumi kepada frekuensi yang dikeluarkan oleh atraktor sebesar 11.000-15.000 Hz. 
ketersediaan jumlah ikan cumi-cumi tersebut lebih banyak dibandingkan jenis ikan lainnya, sehingga memiliki peluang tertangkap yang lebih besar dibandingkan jenis ikan lainnya.

Tabel 2 menunjukkan jumlah jenis hasil tangkapan pada alat tangkap pancing ulur, ikan yang dominan tertangkap adalah jenis ikan cumi-cumi, selar, kuniran, kembung, kerapu, kue, selar tetengkek, dan tenggiri. Komposisi jenis ikan hasil tangkapan juga dapat mengidentifikasi bahwa pada perairan tersebut menunjukkan daerah perairan yang subur akan sumberdaya makanan ikan, ketertarikan cumi-cumi kepada suara yang dihasilkan oleh atraktor sebesar $11.000-15.000 \mathrm{~Hz}$ dapat memicu terjadinya rantai makanan disekitar rumpon portable. Hal tersebut dikarenakan banyaknya jenis ikan pemangsa cumi-cumi dan menyebabkan ikan predator lainnya datang di sekitar rumpon portable. Dengan banyaknya cumi-cumi datang disekitar rumpon portable menyebabkan peluang penangkapan untuk jenis ikan cumi-cumi lebih besar dibandingkan jenis ikan lainnya. Jumlah jenis ikan yang tertangkap disekitar rumpon portable sebanyak 8 jenis ikan, dimana jenis ikan cumicumi dominan tertangkap pada setiap waktu penarikan tali pancing. Selain jenis ikan cumicumi, juga terdapat jenis ikan selar dan kuniran, yang berdasarkan komposisi jenis lebih dari 15,72\% dari hasil tangkapan. Produktivitas penangkapan adalah ukuran kemampuan produksi dari suatu jenis alat tangkap. Produktivitas penangkapan dinyatakan dalam perbandingan antara produksi dengan upaya penangkapan.

Tabel 2. Produksi ikan pelagis kecil di perairan Kabupaten Aceh Utara

\begin{tabular}{cllcc}
\hline No & \multicolumn{1}{c}{ Nama Ikan } & \multicolumn{1}{c}{ Nama Ilmiah } & Berat $(\mathbf{g})$ & Berat $\mathbf{( k g )}$ \\
\hline 1 & Selar tetengkek & Megalaspis cordyla & 1376 & 1,376 \\
2 & Kue & Caranx ignobilis & 201 & 0,201 \\
3 & Kerapu & Epinephelus coioides & 566 & 0,283 \\
4 & Selar & Atule mate & 7013 & 7,535 \\
5 & Cumi-cumi & Loligo indiga & 7217 & 7,403 \\
6 & Kuniran & Upeneus moluccensis & 3508 & 3,508 \\
7 & Tenggiri & Scomberomorus brasiliensis & 1714 & 1,714 \\
8 & Kembung & Rastrelliger brachysoma & 2657 & 2,657 \\
\hline
\end{tabular}

\section{Distribusi frekuensi panjang ikan pada rumpon portable}

Menurut Saputra (2015) metode penentuan selang kelas dan interval kelas sangat membantu dalam proses menentukan ukuran ikan layak tangkap atau belum layak tangkap. Distribusi ukuran hasil tangkapan dianalisis berdasarkan tangkapan dominan pada masing-masing klasifikasi tangkapan yaitu layak tangkap atau belum layak tangkap dengan cara membuat selang kelas (Walpole 1995). Hasil tangkapan yang diperoleh saat penelitian dengan menggunakan rumpon portable menunjukkan terdapat 8 jenis ikan dengan total seluruh tangkapan sebanyak 337 ekor. Ukuran panjang total ikan yang tertangkap di sekitar rumpon portable, jenis ikan selar didominasi pada kisaran 16-17 cm, pada cumi-cumi didominasi pada kisaran 15-18 $\mathrm{cm}$, pada ikan kuniran didominasi pada kisaran 16-18 $\mathrm{cm}$ dan pada ikan kembung didominasi pada kisaran 24-25 cm, hal tersebut dapat dilihat pada Gambar 3, Gambar 4, Gambar 5 dan Gambar 6.
Gambar 3 menunjukkan hasil tangkapan ikan selar kuning yang diperoleh dengan alat tangkap pancing ulur yang dioperasikan di sekitar rumpon portable menunjukkan seluruh hasil tangkapan ikan selar layak tangkap dengan ukuran lebih dari $14 \mathrm{~cm}$, hal itu disebutkan juga oleh Bykov (1983) ukuran ikan selar kuning yang ada di perairan Aceh pertama kali matang gonad (Lm) pada ukuran $11,9 \mathrm{~cm}$.

Gambar 4 menunjukkan hasil tangkapan ikan cumi-cumi yang diperoleh dengan alat tangkap pancing ulur yang dioperasikan di sekitar rumpon portable menunjukkan seluruh hasil tangkapan cumi-cumi layak tangkap dengan ukuran lebih dari $11 \mathrm{~cm}$, Ispahdianto et al. (2016) menyatakan ukuran ikan cumi-cumi yang pertama kali matang gonad (Lm) pada ukuran $>10 \mathrm{~cm}$.

Gambar 5 menunjukkan hasil tangkapan ikan kuniran yang diperoleh dengan alat tangkap pancing ulur yang dioperasikan di sekitar rumpon portable menunjukkan dari seluruh hasil tangkapan ikan kuniran ada 
beberapa yang belum layak tangkap selebihnya layak tangkap dengan ukuran lebih dari 13 $\mathrm{cm}$, hal itu disebutkan juga oleh Saputra et al. (2009) ukuran ikan kuniran pertama kali matang gonad (Lm) pada ukuran $21,81 \mathrm{~cm}$.

Gambar 6 menunjukkan hasil tangkapan ikan kembungyang diperoleh dengan alat tangkap pancing ulur yang dioperasikan di sekitar rumpon portable menunjukkan seluruh hasil tangkapan ikan selar layak tangkap dengan ukuran lebih dari $18 \mathrm{~cm}$. Ispahdianto et al. (2016) menyatakan ukuran ikan kembung yang pertama kali matang gonad (Lm) pada ukuran $>16 \mathrm{~cm}$. Produktivitas penangkapan ikan pelagis di perairan Kabupaten Aceh Utara berdasarkan produksi dari hasil alat tangkap pancing ulur, sebagaimana terlihat pada Gambar 2. Tren produktivitas penangkapan ikan pelagis kecil hubungannya dengan lama waktu penangkapan (Gambar 7) menunjukkan cenderung meningkat dengan bertambah waktu penangkapan. Upaya penangkapan berdasarkan lama waktu pengoperasian alat tangkap menunjukkan adanya kecenderungan produktivitas penangkapan yang semakin meningkat.

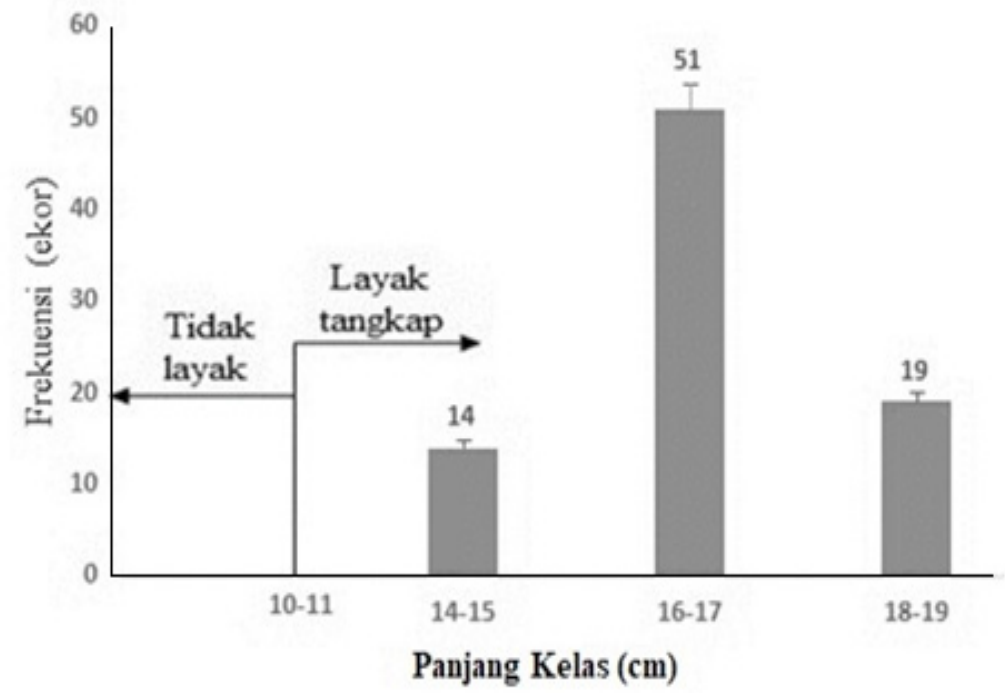

Gambar 3. Frekuensi panjang kelas ikan selar kuning (Selaroides leptolepis)

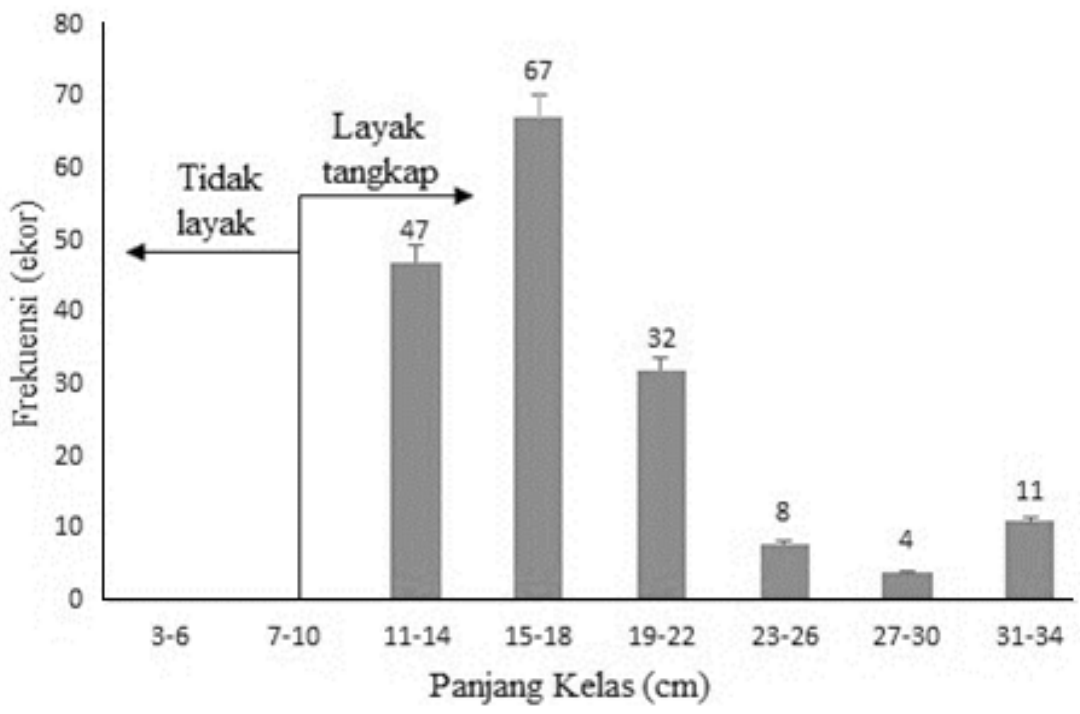

Gambar 4. Frekuensi panjang kelas cumi-cumi (Loligo indiga) 


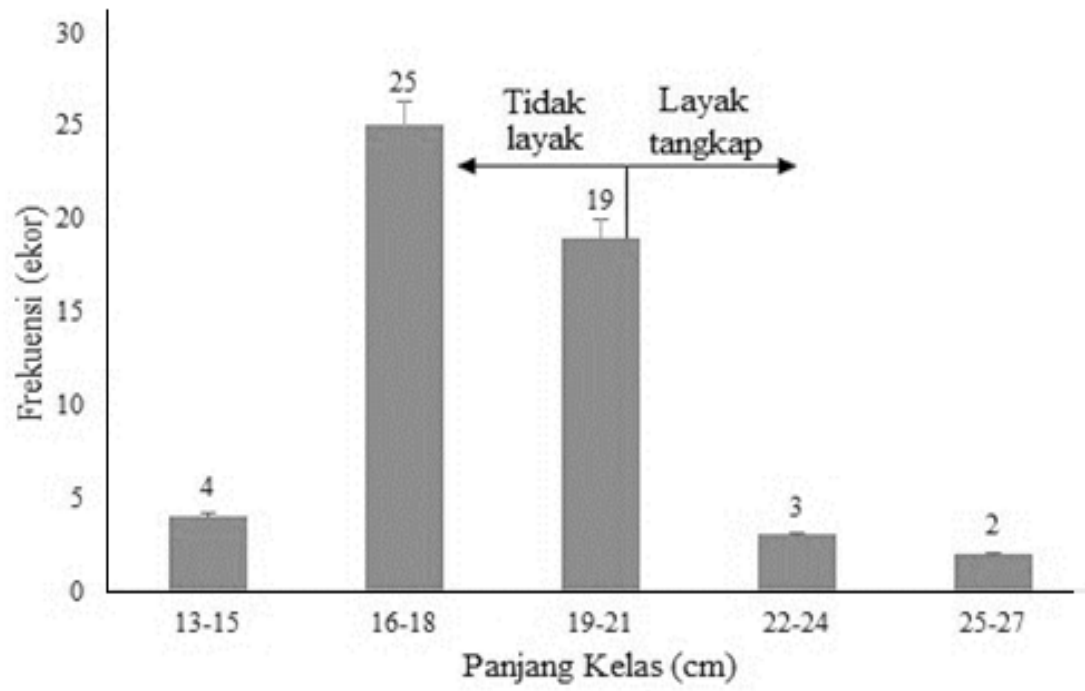

Gambar 5. Frekuensi panjang kelas ikan kuniran (Upeneus moluccensis)

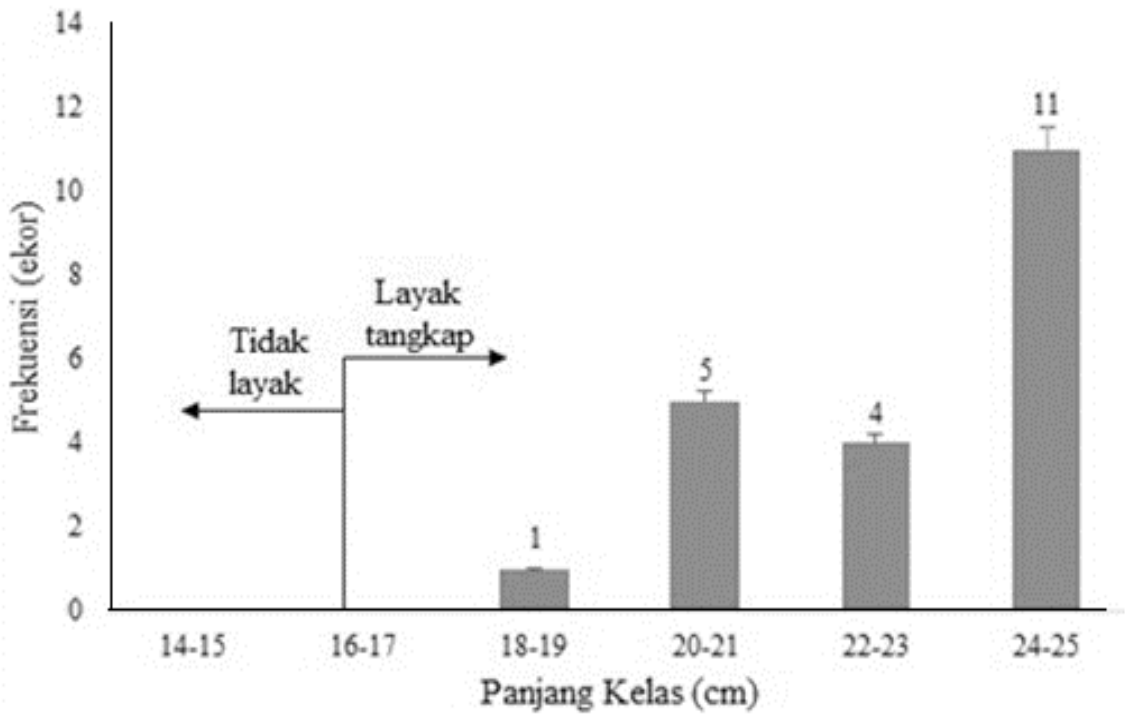

Gambar 6. Frekuensi panjang kelas ikan kembung (Rastrelliger)

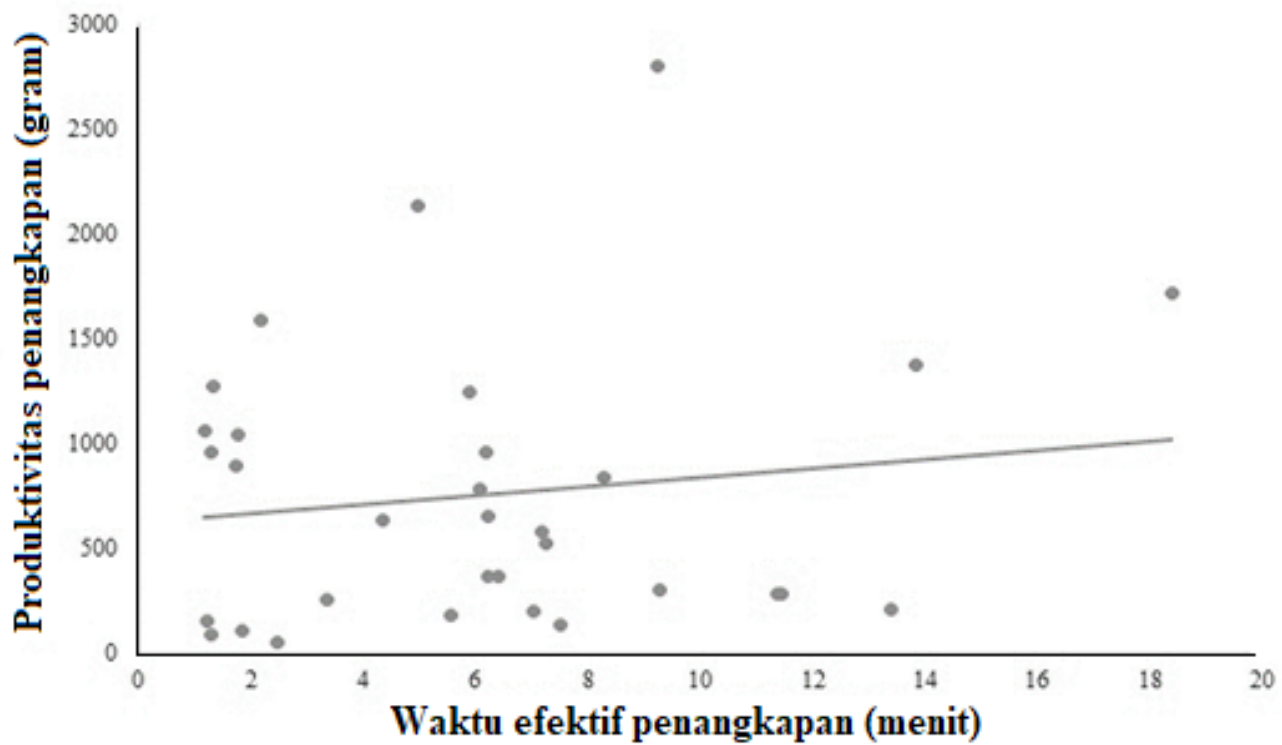

Gambar 7. Tren hubungan produktivitas penangkapan ikan pelagis kecil di perairan Kabupaten Aceh Utara 
Alat tangkap pancingulurmenunjukkan cenderung menghasilkan produksi ikan pelagis kecil, walaupun dalam penggunaan teknologi alat bantu rumpon portable namun pada sisi lain hasil tangkapan yang tidak menggunakan alat bantu rumpon portable lebih besar. Berdasarkan komposisi jenis ikan yang tertangkap dengan alat tangkap pancing ulur yang dioperasikan di sekitar rumpon portable lebih bervariasi hal itu disebabkan karena terjadinya sistem rantai makanan disekitar rumpon portable. Peningkatan upaya penangkapan dengan alat bantu rumpon portable dalam operasi penangkapan ikan akan memberikan dampak pada hasil tangkapan yang lebih bervariasi terhadap ketersediaan ikan pelagis kecil, hal tersebut dikarenakan banyaknya spesies yang datang dan menetap disekitar rumpon portable.

\section{KESIMPULAN DAN SARAN}

\section{Kesimpulan}

Produktivitas penangkapan ikan pelagis kecil dengan menggunakan pancing ulur di sekitar rumpon portable di perairan Aceh Utara sebesar 1,6168 kg/trip menunjukkan cenderung meningkat dengan bertambah waktu penangkapan. Electric fish attractor dengan frekuensi suara $11.000 \mathrm{~Hz}-15.000$ $\mathrm{Hz}$ mendapatkan hasil tangkapan sebanyak 24,25 kg, dari hasil tangkapan keseluruhan menunjukkan cumi-cumi spesies yang paling dominan tertangkap.

\section{Saran}

Dibutuhkan penelitian lanjutan yang berkaitan dengan lama waktu efektif dalam pengoperasian alat tangkap pancing ulur, serta kajian kekuatan rumpon portable terhadap ketahanan saat alat tersebut dioperasikan. Selain itu dibutuhkan adanya penelitian kaitan antara produktivitas hasil tangkapan dengan dengan kondisi arus laut saat melakukan penangkapan.

\section{DAFTAR PUSTAKA}

Adwani. 2011. Perlindungan Sumber Daya Perikanan Laut Sebagai Bentuk Tanggung Jawab Pemerintah Daerah di Perairan Laut di Wilayah Provinsi Aceh. Jurnal Media Hukum. 18 (2) : 190-200.

Badan Meteorologi Klimatologi dan Geofisika (BMKG). 2018. Data Gelombang
Permukaan Air Laut (m) Periode 2018 Kabupaten Aceh Utara. Medan: BMKG Stasiun Meteorologi Maritim Belawan.

Bykov, VP. 1983. Marine Fishes: Chemical Composition and Processing Properies. New Delhi: Amerind Publishing Co. Pvt. Ltd. 322 p.

Ispahdianto D, Fitri ADP, Asriyanto. 2016. Analisis Hasil Tangkapan Ikan Kembung (Rastrelliger Sp) dan Cumi-Cumi (Lolligo Sp) pada Alat Tangkap Mini Purse Seine di Perairan Morodemak, Kabupaten Demak Jawa Tengah. Journal of Fisheries Resources Utilization Management and Technology. 5 (1) : 153-161.

Jaliadi. 2017. Struktur Ukuran dan Hubungan Panjang Berat Ikan Hasil Tangkapan pada Rumpon Portable dan Rumpon Tradisional Diperairan Aceh Barat [tesis]. Bogor (ID): Sekolah Pasca Sarjana Institut Pertanian Bogor. 57 hal.

Muhamad RE, Prayitno, Simbolon D, Yusfiandayani R, Wiryawan B. 2017. Produktivitas Alat Tangkap Yang di Sekitar Rumpon Laut Dalam. Marine Fisheries. 8 (1) : 101-112.

Rasidi S, Harminto S, Wardhana W. (2002). Komunitas plankton dan ikan di perairan rumpon di sekitar Pulau Pramuka (kepulauan Seribu), Teluk Jakarta. Sains Indonesia. 7(2) : 37-44.

Saputra SW, Soedarsono P, Sulistyawati GA. 2009. Beberapa Aspek Biologi Ikan Kuniran (Upeneus Spp) di Perairan Demak. Jurnal Saintek Perikanan. 5 (1) $: 1-6$.

Saputra SW, Anggraeni R, Solichin A. 2015. Beberapa Aspek Biologi Ikan Cakalang (Katsuwonus Pelamis) Dalam Kaitannya untuk Pengelolaan Perikanan di PPP Sadeng Kabupaten Gunungkidul Yogyakarta. Diponegoro Journal Of Maquares. 4 (3).

Shadiqin I, Musman M, Rahmah A. 2016. Penentuan Daerah Penangkapan Potensial Ikan Tuna Mata Besar Dengan Menggunakan Citra Satelit di Perairan Lhokseumawe. Jurnal Ilmiah Mahasiswa Kelautan dan Perikanan Unsyiah. 1 (3): 412-418.

Syari IA, Kawaro M, Baskoro M. (2014). Perbandingan efektivitas rumpon cumicumi menurut musim, kedalaman, dan jenis rumpon. Jurnal penelitian Perikanan Indonesia, 20(1) : 63-72.

Uktolseja JC. (1989). Suatu analisis mengenai perkembangan hasil tangkapan dan upaya penangkapan pola perusahaan 
inti rakyat sistem rumpon di Labuha, Maluku Utara, 1987-1988. Jurnal Penelitian Perikanan Laut (JPPL), 51 : 17-44.

Priatna A, Nugroho D, Mahiswara. (2010). Keberadaan ikan pelagis rumpon laut dalam pada musim Timur di perairan Samudra Hindia sebelah Selatan Teluk Pelabuhan Ratu dengan metode hidroakustik. Jurnal Penelitian Perikanan Indonesia (JPPI), 16(2) : 8391.

Yusfiandayani R, Jaya I, Baskoro MS. 2013. Uji Coba Penangkapan pada Rumpon portable di Perairan Pelabuhanratu. Jurnal Teknologi Perikanan dan kelautan. 4(1) : 89-98.

Walpole. 1995. Pengantar Statistika. Jakarta: Gramedia Pustaka Utama. 